\title{
The Implementation of Learning Management in the Covid-19 Period in Junior High Schools in Indonesia: A Literature Review
}

\author{
Diodantara $^{1}$, Hasan Hariri ${ }^{2}$, Sowiyah ${ }^{3}$ \\ ${ }^{1}$ Student master of Education Administration, Universitas Lampung, Bandar Lampung, Indonesia \\ ${ }^{2,3}$ Faculty of Teacher Training and Education, Universitas Lampung, Bandar Lampung, Indonesia
}

\begin{abstract}
Learning management during the Covid-19 period is important, because it will be able to reduce student boredom in online learning. In addition, by implementing appropriate learning management, it will also be able to help students and teachers to adapt quickly to Covid-19 situation. This study aimed to discover and search for some possible ways on how to implement learning management in Junior High Schools during the Covid-19 period. The method used in this study was literature review with a qualitative research concept. The results of the study indicated that the implementation of learning management during the Covid19 period in Junior High School was carried out by three ways, namely 1) providing social support for students to complete their school work, 2) teachers carry out learning management by reforming learning methods, and 3) good communication management between teachers and students using a platform or application that was in accordance with the material at school.
\end{abstract}

KEYWORDS: Covid-19, Implementation, Learning Management

\section{INTRODUCTION}

Covid 19 has driven various changes in human life, one of which is in the field of education management in junior high schools in Indonesia. [1] Says that psychological constructs adjust students' mental health which can be proposed in school education management. Therefore, during the Covid 19 period, it is necessary to implement learning management that can open students' freedom from the saturation of online learning while at the same time giving meaning to the learning process.

The importance of education management in junior high schools in Indonesia is a form of anticipation by the government and society in providing a pleasant learning atmosphere for students. [2] argues that the emergence of management in education includes the use of administration and management. Therefore, education management in junior high schools intends to emphasize the interactive process between teachers and students or also between a group of students with the aim of continuing the learning process.

Learning during the Covid 19 period in Junior High Schools in Indonesia that occurred online during the Covid 19 period made various parties to be more creative in their implementation. However, there are various problems that arise due to online learning during the Covid 19 period. Based on the online learning survey of SMP N 10 Surabaya during the Covid-19 Emergency which was carried out on 9 - 11 April 2020 on 984 students out of a total of 1401 students, using google form shows that the main thing that becomes the main obstacle in online learning during the Covid-19 Emergency is the limited signal. The survey results can be described as follows:

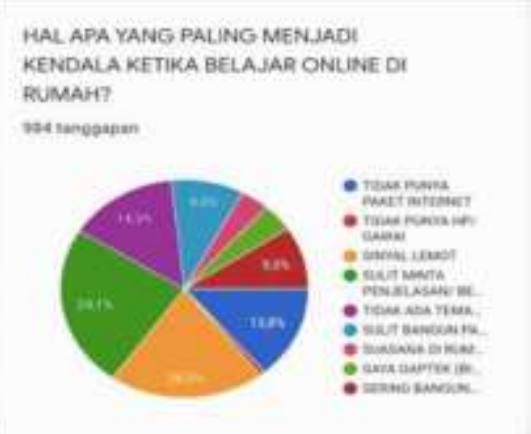

Figure 1 online learning survey of SMP N 10 Surabaya during the Covid-19 Emergency

Source:https://smpn10surabaya.sch.id/survei-pembelajaran-daring-smpn-10-surabaya-di-masa-darurat-covid-19-inilah -result/ 


\section{International Journal of Current Science Research and Review}

ISSN: 2581-8341

Volume 04 Issue 07 July 2021

DOI: 10.47191/ijcsrr/V4-i7-24, Impact Factor: 5.825

IJCSRR @ 2021

WwW.ijcsrr.org

Based on Figure 1 online learning survey of SMP N 10 Surabaya during the Covid-19 Emergency, it was found that 24.1\% of students admitted that online learning made it difficult, 20.3\% slow signals, $14.3 \%$ no study friends. [3] says that internal management provides a broader public management-based analysis of strategy, policy, and service delivery. Therefore, the importance of education management in junior high schools requires planning so that the work will get optimal results.

Education management in junior high schools in Indonesia can be used as a pillar in the successful implementation of the teaching and learning process. In junior high schools in Indonesia, learning management is an effort to regulate the teaching and learning process in order to achieve effective and efficient learning objectives. [4] Said that university life in learning management builds identity by articulating an environment that supports teaching and learning. Therefore, education management in junior high schools in Indonesia must be directed not only to activities carried out by teachers but also to learning that includes all activities that affect teaching and learning outcomes.

The existence of planning in the implementation of learning management during the Covid 19 period in junior high schools in Indonesia is expected to help in meaningful implementation and not leave the function of education management. [5] Said that education management reveals four main activities; covering education development, educational assessment, research development, and research assessment; in education management. Therefore, the implementation of learning management during the Covid 19 period in junior high schools in Indonesia is also in increasing the effectiveness of learning so that learning can take place optimally.

The implementation of learning management during the Covid 19 period in junior high schools in Indonesia is an effort to minimize passive learning. [6] Said that learning management is a term used in the world of learning, which consists of two words. The first word is "management" which is the effective use of resources to achieve goals. While the second word is "learning" which means the process, method, action that makes people or living things learn. Therefore, learning management during the Covid 19 period is the use of learning management resources to achieve learning goals.

\section{METHOD}

This systematic literature review used a qualitative approach. A qualitative approach is a research that produces descriptive data in the form of words, so that what was produced in this study was descriptive in the form of words related to the implementation of learning management during the Covid-19 period in junior high schools in Indonesia [7].

Meanwhile, the method used in this research was a systematic literature review with various reference documents relevant to the implementation of learning management during the Covid-19 period in junior high schools in Indonesia. The documentation was done by looking for data about variables in the form of notes, transcripts, newspapers, magazines, inscriptions, minutes, agendas and so on [8]. Therefore, in this study, we searched for data on variables in the form of notes, transcripts, newspapers, magazines, inscriptions, minutes regarding the implementation of learning management during the Covid-19 period in junior high schools in Indonesia.

In the results and discussion section, we presented the results of a literature study regarding the implementation of learning management during the Covid-19 period in junior high schools in Indonesia. The research on literature study was obtained from various articles, journals and books that discussed the implementation of learning management during the Covid 19 period in junior high schools in Indonesia.

\section{RESULTS AND DISCUSSION}

In the results and discussion section, the author presents the results of a literature study regarding the implementation of learning management during the Covid 19 period in junior high schools in Indonesia. The research literature study was obtained from various articles, journals and books discussing the implementation of learning management during the Covid 19 period in junior high schools in Indonesia. The following are the results of the literature study table that the researchers got: 


\section{International Journal of Current Science Research and Review}

ISSN: 2581-8341

Volume 04 Issue 07 July 2021

DOI: 10.47191/ijcsrr/V4-i7-24, Impact Factor: 5.825

IJCSRR@ 2021

www.ijcsrr.org

Table 1 the results of the literature study table that was researched

\begin{tabular}{|c|c|c|c|c|c|}
\hline No & Author & Title and Year & Country & Method & Results \\
\hline 1 & $\begin{array}{l}\text { X. Wang, Q. } \\
\text { Zheng, } \\
\text { dan X. Cao, }\end{array}$ & $\begin{array}{l}\text { Psychological Capital: A New } \\
\text { Perspective for Psychological } \\
\text { Health Education } \\
\text { Management of Public } \\
\text { Schools (2014) }\end{array}$ & China & Qualitative & $\begin{array}{l}\text { psychological constructs adjust } \\
\text { students' mental health that can } \\
\text { be proposed in school } \\
\text { education management }\end{array}$ \\
\hline 2 & P. Sapre & $\begin{array}{l}\text { Realizing the Potential of } \\
\text { Education } \\
\text { Management in India } \\
(2002)\end{array}$ & India & Qualitative & $\begin{array}{l}\text { The emergence of management } \\
\text { in education includes the use of } \\
\text { administration and management. } \\
\text { Therefore, education } \\
\text { management in junior high } \\
\text { schools intends to emphasize the } \\
\text { interactive process between } \\
\text { teachers and students or also } \\
\text { between a groups of students } \\
\text { with the aim of continuing the } \\
\text { learning process. }\end{array}$ \\
\hline 3 & D. McTavish & $\begin{array}{l}\text { Further Education Management } \\
\text { Strategy and Policy: } \\
\text { Institutional and Public } \\
\text { Management } \\
\text { Dimensions (2006) }\end{array}$ & Inggris Raya & Qualitative & $\begin{array}{l}\text { Internal management provides a } \\
\text { broader public management } \\
\text { based analysis of strategy, } \\
\text { policy, and service delivery. } \\
\text { Therefore, the importance of } \\
\text { education management in junior } \\
\text { high schools requires planning } \\
\text { so that the work will get optimal } \\
\text { results. }\end{array}$ \\
\hline 4 & S. A. Balasanyan, & $\begin{array}{l}\text { From pedagogy to quality: the } \\
\text { Europeanised experience of } \\
\text { higher education in post- } \\
\text { Soviet Armenia (2017) }\end{array}$ & $\begin{array}{l}\text { Republic } \\
\text { of } \\
\text { Armenia }\end{array}$ & Qualitative & $\begin{array}{l}\text { Saying that university life on } \\
\text { learning management builds } \\
\text { identity by articulating an } \\
\text { environment that supports } \\
\text { teaching and learning. } \\
\text { Therefore, } \\
\text { management in junior high } \\
\text { schools in Indonesia must be } \\
\text { directed not only to activities } \\
\text { carried out by teachers but also } \\
\text { to learning that includes all } \\
\text { activities that affect teaching and } \\
\text { learning outcomes. }\end{array}$ \\
\hline
\end{tabular}




\section{International Journal of Current Science Research and Review}

ISSN: 2581-8341

Volume 04 Issue 07 July 2021

DOI: 10.47191/ijesrr/V4-i7-24, Impact Factor: 5.825

IJCSRR@ 2021

Www.ijesrr.org

\begin{tabular}{|c|c|c|c|c|c|}
\hline 5 & $\begin{array}{l}\text { M. M. Habib dan } \\
\text { B. B. Pathik }\end{array}$ & $\begin{array}{l}\text { An Investigation of } \\
\text { Education and Research } \\
\text { Management for } \\
\text { Academic Institutions } \\
\text { (2021) }\end{array}$ & USA & Qualitative & $\begin{array}{l}\text { That education management } \\
\text { reveals four main activities; } \\
\text { covering } \\
\text { development, } \\
\text { assessment, educational } \\
\text { development, and research } \\
\text { assessment; in education } \\
\text { management. Therefore, the } \\
\text { implementation of learning } \\
\text { management during the Covid } \\
19 \text { period in junior high schools } \\
\text { in Indonesia is also in increasing } \\
\text { the effectiveness of learning so } \\
\text { that learning can take place } \\
\text { optimally. }\end{array}$ \\
\hline 6 & S. Kumar & $\begin{array}{l}\text { Mind Your Education: Text of a } \\
\text { Speech delivered at the National } \\
\text { Seminar on Management } \\
\text { Education at Banglaore on 26th } \\
\text { July } 2004 \\
(2004)\end{array}$ & India & Qualitative & $\begin{array}{l}\text { Some deficiencies in education } \\
\text { management ensure minimum } \\
\text { quality standards. Therefore, in } \\
\text { the learning process, all aspects } \\
\text { of student intelligence must also } \\
\text { be managed, including } \\
\text { providing social support to } \\
\text { students. }\end{array}$ \\
\hline 7 & $\begin{array}{l}\text { K. Mather dan R. } \\
\text { Seifert }\end{array}$ & $\begin{array}{l}\text { Teacher, lecturer } \text { or labourer? } \\
\text { Performance } \\
\text { issues in education }(2011)\end{array}$ & England & Qualitative & $\begin{array}{l}\text { Educational management is } \\
\text { dominated by general } \\
\text { management norms that focus } \\
\text { on controlling performance and } \\
\text { achieving targets. Therefore, } \\
\text { social support in learning } \\
\text { management during the Covid } \\
19 \text { period in Junior High Schools } \\
\text { is a form of part of the learning } \\
\text { principle. }\end{array}$ \\
\hline 8 & $\begin{array}{l}\text { K. Li, M. Jing, X. } \\
\text { Tao, dan Y. Duan }\end{array}$ & $\begin{array}{l}\text { Research on } \quad \text { online } \\
\text { management system of network } \\
\text { ideological and political } \\
\text { education of college students } \\
(2021)\end{array}$ & China & Qualitative & $\begin{array}{l}\text { With the development of a } \\
\text { network society, student life is } \\
\text { enveloped by the community } \\
\text { network. }\end{array}$ \\
\hline
\end{tabular}




\section{International Journal of Current Science Research and Review}

ISSN: 2581-8341

Volume 04 Issue 07 July 2021

DOI: 10.47191/ijcsrr/V4-i7-24, Impact Factor: 5.825

IJCSRR@ 2021

www.ijesrr.org

\begin{tabular}{|c|c|c|c|c|c|}
\hline 9 & D. K. Yadav & $\begin{array}{l}\text { Student Engagement at Higher } \\
\text { Education Institutions: A Study } \\
\text { of International Student } \\
\text { Engagement and Motivational } \\
\text { Challenges at Chinese } \\
\text { Universities (2021) }\end{array}$ & China & Qualitative & $\begin{array}{l}\text { The challenge in dealing with } \\
\text { difficulties in involving students } \\
\text { is to raise students' enthusiasm. } \\
\text { Therefore, during the Covid } 19 \\
\text { era, educational management by } \\
\text { providing enthusiasm will } \\
\text { arouse students' sense of } \\
\text { learning so that they will have a } \\
\text { passionate interest in learning } \\
\text { and sacrifice to achieve learning } \\
\text { goals. }\end{array}$ \\
\hline 10 & S. Gorard & $\begin{array}{l}\text { Current Contexts for } \\
\text { Research in Educational } \\
\text { Leadership and } \\
\text { Management (2005) }\end{array}$ & England & Qualitative & $\begin{array}{l}\text { In the leadership and } \\
\text { management of school work has } \\
\text { led to a number of initiatives that } \\
\text { are intended to improve the } \\
\text { situation. } \\
\text { Therefore, in social support to } \\
\text { students as management } \\
\text { between the learning process } \\
\text { and changes in learning. Social } \\
\text { support for students in junior } \\
\text { high schools in learning during } \\
\text { the Covid } 19 \text { period can provide } \\
\text { encouragement for students to } \\
\text { complete their work. Students } \\
\text { who have a passion for learning } \\
\text { will want to immediately do the } \\
\text { assignments given by the } \\
\text { teacher }\end{array}$ \\
\hline 11 & $\begin{array}{l}\text { S. Zhao, Z. Su, dan } \\
\text { G. Miao }\end{array}$ & $\begin{array}{l}\text { Application of } \begin{array}{r}\text { English } \\
\text { education }\end{array} \\
\text { management } \\
\text { information }\end{array}$ & China & Qualitative & $\begin{array}{l}\text { Social support in students can } \\
\text { build a management system in } \\
\text { education more useful. } \\
\text { Therefore, when there is social } \\
\text { support for students in } \\
\text { management. }\end{array}$ \\
\hline 12 & Z. Pang & 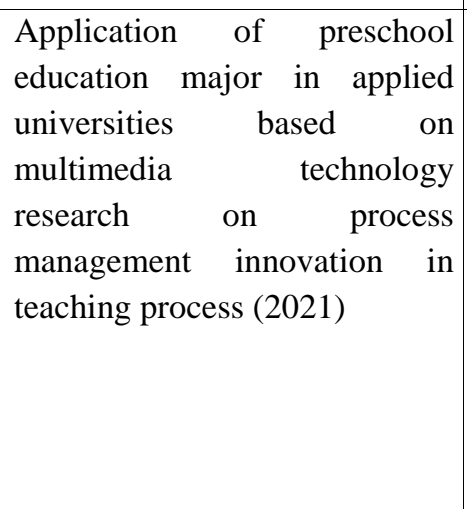 & China & Qualitative & $\begin{array}{l}\text { In the development of } \\
\text { education, innovation and } \\
\text { practice become a very } \\
\text { important concern. Therefore, } \\
\text { the author can conclude that } \\
\text { based on the results of research } \\
\text { on providing social support to } \\
\text { students to be able to complete } \\
\text { their school work during the } \\
\text { Covid } 19 \text { period, students will } \\
\text { be enthusiastic in receiving }\end{array}$ \\
\hline
\end{tabular}




\section{International Journal of Current Science Research and Review}

ISSN: 2581-8341

Volume 04 Issue 07 July 2021

DOI: 10.47191/ijesrr/V4-i7-24, Impact Factor: 5.825

IJCSRR@ 2021

www.ijesrr.org

\begin{tabular}{|c|c|c|c|c|c|}
\hline & & & & & $\begin{array}{l}\text { lessons because students want } \\
\text { challenges. }\end{array}$ \\
\hline 13 & $\begin{array}{l}\text { C. H. Roch dan N. } \\
\text { Sai, }\end{array}$ & $\begin{array}{l}\text { Charter School Teacher Job } \\
\text { Satisfaction, (2016) }\end{array}$ & USA & Qualitative & $\begin{array}{l}\text { Working conditions in schools } \\
\text { cause different levels of job } \\
\text { satisfaction among teachers and } \\
\text { students say that learning in a } \\
\text { fresh state will be better than the } \\
\text { results. Therefore, with the spirit } \\
\text { of learning students will always } \\
\text { have a fresh state in learning }\end{array}$ \\
\hline 14 & R. Doncaster & $\begin{array}{l}\text { Learning } \quad \text { and } \\
\text { Managing } \\
\text { (1979) }\end{array}$ & USA & Qualitative & $\begin{array}{l}\text { To develop a relationship in } \\
\text { learning, it is important to } \\
\text { reflect on what experiences have } \\
\text { developed for him. }\end{array}$ \\
\hline 15 & $\begin{array}{l}\text { O. Chernikova, N. } \\
\text { Heitzmann, M. } \\
\text { Stadler, } \\
\text { Holzberger, } \\
\text { T. Seidel, dan F. } \\
\text { Fischer, }\end{array}$ & $\begin{array}{l}\text { Simulation-Based } \\
\text { Learning in Higher } \\
\text { Education: A Meta- } \\
\text { Analysis ( 2020) }\end{array}$ & Jerman & Qualitative & $\begin{array}{l}\text { That opportunities to practice } \\
\text { complex skills in education } \\
\text { facilitate effective learning. } \\
\text { Therefore, in implementing } \\
\text { learning management during the } \\
\text { Covid } 19 \text { period, implementing } \\
\text { variations in learning methods is } \\
\text { one of the empowerment of } \\
\text { resources by teachers. }\end{array}$ \\
\hline 16 & N. O. Pansiri & $\begin{array}{l}\text { Performativity in School } \\
\text { Management and Leadership in } \\
\text { Botswana (2011) }\end{array}$ & Botswana & Qualitative & $\begin{array}{l}\text { That education management and } \\
\text { uncritical leadership policies } \\
\text { result in poor performance in } \\
\text { schools in disadvantaged } \\
\text { communities. Therefore, it can } \\
\text { be seen in Figure } 2 \text { that the } \\
\text { learning components consist of } \\
\text { evaluation, goals, educators, } \\
\text { students, curriculum, strategy, } \\
\text { media, and evaluation } \\
\text { Therefore, in a variety of } \\
\text { learning methods, al } \\
\text { components of learning will be } \\
\text { brought together. }\end{array}$ \\
\hline
\end{tabular}




\section{International Journal of Current Science Research and Review}

ISSN: 2581-8341

Volume 04 Issue 07 July 2021

DOI: 10.47191/ijesrr/V4-i7-24, Impact Factor: 5.825

IJCSRR@ 2021

Www.ijesrr.org

\begin{tabular}{|c|c|c|c|c|c|}
\hline 17 & C. Grant & $\begin{array}{l}\text { Emerging Voices on Teacher } \\
\text { Leadership: Some South } \\
\text { African Views ( 2006) }\end{array}$ & South African & Qualitative & $\begin{array}{l}\text { Hierarchical and bureaucratic } \\
\text { management styles in learning } \\
\text { make strategic proposals for } \\
\text { education management capacity, } \\
\text { including self-management } \\
\text { approaches to schools and } \\
\text { implicitly support the idea of } \\
\text { teacher leadership for the new } \\
\text { dispensation. Therefore, the } \\
\text { variation of learning methods } \\
\text { during the Covid } 19 \text { period is } \\
\text { essentially an activity that } \\
\text { expects changes in student } \\
\text { behavior. }\end{array}$ \\
\hline 18 & M. Jacobi & $\begin{array}{l}\text { Mentoring and } \\
\text { Undergraduate Academic } \\
\text { Success: A Literature Review } \\
\text { (1991) }\end{array}$ & USA & Qualitative & $\begin{array}{l}\text { Management as a series of } \\
\text { activities directed to achieve } \\
\text { goals effectively and efficiently. } \\
\text { Therefore, in the } \\
\text { implementation of learning } \\
\text { management during the Covid } \\
19 \text { period, variou learning } \\
\text { methods were carried out, } \\
\text { namely the process of } \\
\text { organizing to achieve learning } \\
\text { objectives. }\end{array}$ \\
\hline 19 & S. Vergari & $\begin{array}{l}\text { The Politics of Charter Schools } \\
\text { (2007) }\end{array}$ & USA & Qualitative & $\begin{array}{l}\text { In issues related to developing } \\
\text { an operational definition of } \\
\text { mentoring standards in } \\
\text { education provides a critical } \\
\text { review of empirical research on } \\
\text { mentoring and education. } \\
\text { Therefore, to make learning } \\
\text { successful at junior high schools } \\
\text { in Indonesia during the Covid } 19 \\
\text { period, the management } \\
\text { function can be said to be } \\
\text { coordinating learning methods } \\
\text { for students. }\end{array}$ \\
\hline
\end{tabular}




\section{International Journal of Current Science Research and Review}

ISSN: 2581-8341

Volume 04 Issue 07 July 2021

DOI: 10.47191/ijcsrr/V4-i7-24, Impact Factor: 5.825

IJCSRR@ 2021

Www.ijesrr.org

\begin{tabular}{|c|c|c|c|c|c|}
\hline 20 & M. Dobbins, & $\begin{array}{l}\text { Convergent or divergent } \\
\text { Europeanization? An analysis } \\
\text { of higher education governance } \\
\text { reforms in France and } \\
\text { Italy ( 2015) }\end{array}$ & Italy & Qualitative & $\begin{array}{l}\text { Advancing perspectives on } \\
\text { education policy and student } \\
\text { self-reliance begins with a } \\
\text { framework for examining in } \\
\text { terms of the mobilizing power of } \\
\text { the two advocacy coalitions } \\
\text { rather than by data on student } \\
\text { performance. Therefore, in the } \\
\text { variation of the action-directed } \\
\text { learning method, it is to try to } \\
\text { achieve the learning goals by } \\
\text { itself. }\end{array}$ \\
\hline 21 & A. H. Anshori. & $\begin{array}{l}\text { The Importance } \\
\text { School/ Madrasah } \\
\text { Management in } \\
\text { Effective } \\
\text { School/Madrasah } \\
\text { Leadership (2016) }\end{array}$ & Indonesia & Qualitative & $\begin{array}{l}\text { Problems with education in } \\
\text { Indonesia, the World Bank, } \\
\text { recommends five strategies that } \\
\text { need to be observed, namely; (1) } \\
\text { an inclusive curriculum, (2) an } \\
\text { effective teaching and learning } \\
\text { process, (3) a supportive school } \\
\text { environment, (4) resources } \\
\text { based on equity, and (5) } \\
\text { standardization of certain } \\
\text { matters, monitoring, evaluation, } \\
\text { and tests. The five strategies } \\
\text { must be integrated into the scope } \\
\text { of the school's management } \\
\text { (management) function, namely: } \\
\text { organizational management, } \\
\text { leadership, teaching and } \\
\text { learning processes, human } \\
\text { resources, and school } \\
\text { administration. }\end{array}$ \\
\hline 22 & N. Fathurrohman & $\begin{array}{l}\text { Urgency } \\
\text { Management Education for } \\
\text { Students (Case Study on } \\
\text { Implementation of Student } \\
\text { Organizations at the Faculty of } \\
\text { Islamic Religion } \\
\text { UNSIKA) }\end{array}$ & Indonesia & Qualitative & $\begin{array}{l}\text { Management is an activity that is } \\
\text { used to manage everything } \\
\text { properly, in order to carry out } \\
\text { activities effectively and } \\
\text { efficiently. Therefore, the use of } \\
\text { variations in teaching in learning } \\
\text { during the Covid } 19 \text { period in } \\
\text { Junior High Schools is a way to } \\
\text { manage everything well, so that } \\
\text { learning activities can be carried } \\
\text { out effectively and efficiently in } \\
\text { the classroom. }\end{array}$ \\
\hline
\end{tabular}




\section{International Journal of Current Science Research and Review}

ISSN: 2581-8341

Volume 04 Issue 07 July 2021

DOI: 10.47191/ijcsrr/V4-i7-24, Impact Factor: 5.825

IJCSRR@ 2021

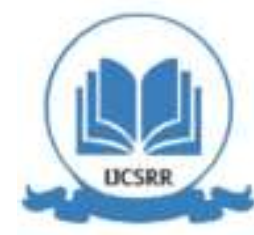

www.ijcsrr.org

\begin{tabular}{|c|c|c|c|c|c|}
\hline 23 & M. Adnan & $\begin{array}{l}\text { The Urgency of Application of } \\
\text { Islamic Education Management } \\
\text { in the Global Era (2019) }\end{array}$ & Indonesia & Qualitative & $\begin{array}{l}\text { Education has a central role for } \\
\text { human resource development } \\
\text { efforts. In learning during the } \\
\text { Covid } 19 \text { period in Junior High } \\
\text { Schools, variation in teaching is } \\
\text { a process for improving } \\
\text { residual skills }\end{array}$ \\
\hline 24 & E. F. Rahayu & $\begin{array}{l}\text { Learning Management in the } \\
\text { Context of } \quad \text { Developing } \\
\text { Multiple Intelligences of } \\
\text { Students } \\
\text { (2015) }\end{array}$ & Indonesia & Qualitative & $\begin{array}{l}\text { Learning management planning } \\
\text { in the context of developing } \\
\text { multiple intelligences. So by } \\
\text { using variations in teaching in } \\
\text { learning during the Covid } 19 \\
\text { period in junior high schools, } \\
\text { you will be able to optimally } \\
\text { teach students. }\end{array}$ \\
\hline 25 & A. H. Anshori. & $\begin{array}{l}\text { The Importance of } \\
\text { School/MadrasahBased } \\
\text { Management in } \\
\text { Effective } \\
\text { School/Madrasah } \\
\text { Leadership (2016) }\end{array}$ & Indonesia & Qualitative & $\begin{array}{l}\text { As a supervisor, the principal is } \\
\text { obliged to help teachers improve } \\
\text { the ability of teachers in the } \\
\text { academic field to teach students } \\
\text { optimally. So in learning during } \\
\text { the Covid } 19 \text { period in junior } \\
\text { high schools, supervisors can } \\
\text { accompany teachers in terms of } \\
\text { using variations in teaching. }\end{array}$ \\
\hline
\end{tabular}

1) Provide Social Support to Students to Be Able to Complete Their Schoolwork

The results of the study show that the implementation of learning management during the Covid 19 period in junior high schools in Indonesia can be done by providing social support to students to be able to complete their school work. [9] Said that some deficiencies in education management ensure minimum quality standards. Therefore, in the learning process, all aspects of student intelligence must also be managed, including providing social support to students.

Providing social support to students to be able to complete their school work in implementing learning management during the Covid 19 period in Junior High Schools in Indonesia means a process of planning, and controlling learning management resources so that effective learning is produced. [10] Say that educational management is dominated by general management norms that focus on controlling performance and achieving targets. Therefore, social support in learning management during the Covid 19 period in Junior High Schools is a form of part of the learning principle.

The results showed that in learning management for junior high schools it is necessary to apply a learning process that can arouse students' enthusiasm. [11] Said that with the development of a network society, student life was enveloped by a network society. Then [12] said that the challenge in facing difficulties in involving students was to raise students' enthusiasm. Therefore, during the Covid 19 era, educational management by providing enthusiasm will arouse students' sense of learning so that they will have a passionate interest in learning and sacrifice to achieve learning goals.

Providing social support to students to be able to complete their school work is expected to be able to provide changes in student learning. [13] Said that in leadership and school work management has led to a number of initiatives that are intended to improve the situation. Therefore, in social support to students as management between the learning process and changes in learning. Social support for students in junior high schools in learning during the Covid 19 period can provide encouragement for students to complete their work. Students who have a passion for learning certainly want to immediately do the assignments given by the 


\section{International Journal of Current Science Research and Review}

ISSN: 2581-8341

Volume 04 Issue 07 July 2021

DOI: 10.47191/ijcsrr/V4-i7-24, Impact Factor: 5.825

IJCSRR@ 2021

www.ijcsrr.org

teacher. [14] Stating that social support for students can build a management system in education is more useful. Therefore, when there is social support for students in management.

Learning during the Covid 19 period will minimize signs of laziness in students. [15] Said that in the development of education, innovation and practice became a very important concern. Therefore, the author can conclude that based on the results of research on providing social support to students to be able to complete their school work during the Covid 19 period, students will be enthusiastic in receiving lessons because students want challenges. [16] Said working conditions in schools led to different levels of job satisfaction among teachers and students said that learning in a fresh state would be better than the results. Therefore, with the spirit of learning, students will always have a fresh state in learning.

\section{2) Teachers Implement Learning Management Namely By Performing Variations in Learning Methods.}

The results of the study show that the implementation of learning management during the Covid 19 period in junior high schools in Indonesia can be done by teachers implementing learning management, namely by varying learning methods. [17] Said that in order to develop a relationship in learning, it is important to reflect on what experiences have developed for him. [18] Say that opportunities to practice complex skills in education facilitate effective learning. Therefore, in implementing learning management during the Covid 19 period, implementing variations in learning methods is one of the empowerment of resources by teachers.

Variations in learning methods during the Covid 19 period in junior high schools in Indonesia will emphasize the learning component. [19] Say that education management and uncritical leadership policies result in poor performance in schools in disadvantaged communities. Therefore, it can be seen in Figure 2 that the learning components consist of evaluation, goals, educators, students, curriculum, strategy, media, and evaluation. Therefore, variations in learning methods will bring together all the components of learning

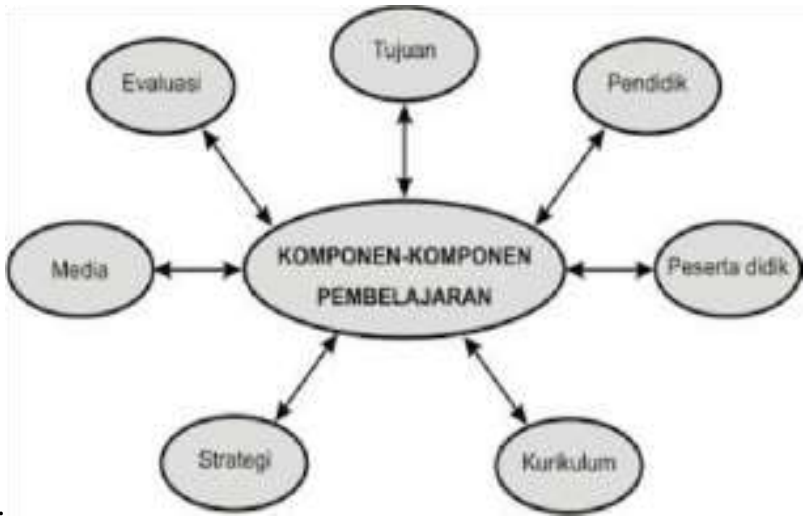

Source: http://www.glendomi.com/2012/10/komponen-komponen-pembelajaran_3.html

In junior high schools in Indonesia, variations in learning methods during the Covid 19 period provide a student learning experience. [20] Say that hierarchical and bureaucratic management styles in learning make strategic proposals for education management capacity, including self-management approaches to schools and implicitly support the idea of teacher leadership for the new dispensation. Therefore, the variation of learning methods during the Covid 19 period is essentially an activity that expects changes in student behavior.

In junior high schools in Indonesia, the variation of learning methods is to use learning management that is tailored to the student's situation. [22] Said that management as a series of activities directed to achieve goals effectively and efficiently. Therefore, in the implementation of learning management during the Covid 19 period, various learning methods were carried out, namely the process of organizing to achieve learning objectives.

Varying learning methods in learning management during the Covid 19 period means affirming the function of management in the learning process. [21] Said that in issues related to the development of an operational definition of mentoring standards in education, it provides a critical review of empirical research on mentoring and education. Therefore, to make learning successful at 


\section{International Journal of Current Science Research and Review}

ISSN: 2581-8341

Volume 04 Issue 07 July 2021

DOI: 10.47191/ijcsrr/V4-i7-24, Impact Factor: 5.825

IJCSRR@ 2021

www.ijcsrr.org

junior high schools in Indonesia during the Covid 19 period, the management function can be said to be coordinating learning methods for students.

The results showed that variations in learning methods will be able to foster student independence in learning and also foster leadership. [22] Argue that advancing perspectives on education policy and student self-reliance begins with a framework for examining in terms of the mobilizing power of the two advocacy coalitions rather than by data on student performance. Therefore, in the variation of the action-directed learning method, it is to try to achieve the learning goals by itself.

\section{3) The existence of good communication management between teachers and students by using a platform or application that} is in accordance with the material at school.

The results of the study show that the implementation of learning management during the Covid 19 period in junior high schools in Indonesia can be carried out with good communication management between teachers and students by using a platform or application that is in accordance with the material at school. [23] Said that using empirical indicator schemes, divergent and convergent development played a pioneering role in education by linking institutional isomorphism with historical institutionalism. Therefore, the existence of good communication management between teachers and students will align functions in the benefits of learning objectives.

The existence of good communication management between teachers and students in learning during the Covid 19 period at Junior High Schools in Indonesia is part of the planning and design of the learning system. Robert F. Mager (1965) in [24] said that learning objectives are behaviors to be achieved or that can be done by students under certain conditions and levels of competence. Therefore, in good communication between teachers and students there will be behavior to be achieved for students and can also help students achieve a certain level of competence. Good communication between teachers and students in learning during the Covid 19 period at junior high schools in Indonesia is to create a good communication situation. It can be seen in Figure 3 regarding communication in learning that there are various interactions between teachers and students in the learning process.

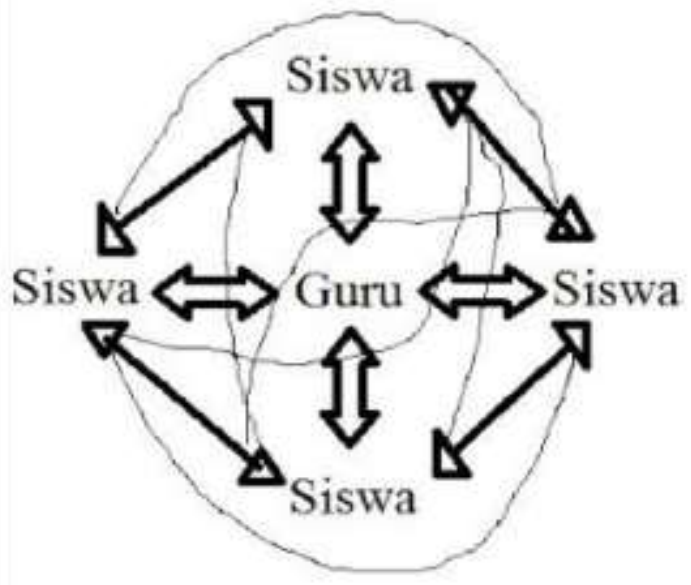

Figure 3. Multi-way Communication Pattern

Source: http://www.kampus-digital.com/2017/03/pola-komunikasi-dalam-proses-belajar.html

Based on Figure 3 about the pattern of multidirectional communication, there are various movements between the teacher and students. Therefore, good communication management between teachers and students in learning during the Covid 19 period in Junior High School is a design for actualizing the basic values of communication in learning. [25] Said that community participation in the management of school education has emerged as one of the most prominent features in all educational development programs at the global level. Therefore, in good communication between teachers and students there will be a teaching and learning process aimed at overcoming boredom and improve student learning outcomes in the classroom. 26] said the purpose of using variety in teaching is 1) Increasing and maintaining student attention, 2) Providing opportunities for the possible functioning of motivation 3) Forming positive attitudes towards teachers and schools 4) Providing possibilities for individual learning options and facilities. Then 


\section{International Journal of Current Science Research and Review}

ISSN: 2581-8341

Volume 04 Issue 07 July 2021

DOI: 10.47191/ijesrr/V4-i7-24, Impact Factor: 5.825

IJCSRR@ 2021

www.ijcsrr.org

[27] said that a number of the main challenges in managing education effectively identify the threats posed by some of the challenges in education, teacher and student.

\section{CONCLUSION}

We could conclude that that the implementation of learning management during the Covid-19 period in junior high school could be carried out by providing social support for students to be able to complete their school work, teachers could carry out learning management by changing learning methods, and conducting good communication management between teachers and students using a platform or application in accordance with the material at school. Learning management during the Covid-19 period was important, because it was able to reduce students' boredom during online learning. In addition, by implementing proper learning management, it could help students and teachers to be able to adapt quickly to the Covid-19 situation.

\section{ACKNOWLEDGEMENTS}

We thanked to Mr Hasan Hariri, S.Pd., MBA, PhD and Mrs Dr. Sowiyah M.Pd as a lecturer in the course writing and presentation of scientific articles who has guided the author in writing this article until its completion. We also thanked to our friends Student master of administration Universitas Lampung 2020 for the discussion.

\section{REFERENCES}

1. X. Wang, Q. Zheng, dan X. Cao, "Psychological Capital: A New Perspective for Psychological Health Education Management of Public Schools," Public Pers. Manage., vol. 43, no. 3, hal. 371-383, Mei 2014.

2. P. Sapre, "Realizing the Potential of Education Management in India," Educ. Manag. Adm., vol. 30, no. 1, hal. 101-108, Jan 2002.

3. D. McTavish, "Further Education Management Strategy and Policy: Institutional and Public Management Dimensions," Educ. Manag. Adm. Leadersh., vol. 34, no. 3, hal. 411-428, Jul 2006.

4. S. A. Balasanyan, "From pedagogy to quality: the Europeanised experience of higher education in post-Soviet Armenia," Eur. Educ. Res. J., vol. 17, no. 4, hal. 584-601, Agu 2017.

5. M. M. Habib dan B. B. Pathik, "An Investigation of Education and Research Management for Tertiary Academic Institutions," Int. J. Eng. Bus. Manag., vol. 4, hal. 1, Jan 2012.

6. Alwi Dkk, Kamus Besar Bahasa Indonesia. Jakarta: Balai Pustaka, 2002.

7. L. J. Moleong, Qualitative Research Methods. Revised Edition. Bandung: PT. Remaja Rosdakarya, 2011.

8. S. Arikunto, Prosedur Penelitian Suatu Pendekatan Praktek. Jakarta: PT. Rineka Cipta, 2006.

9. S. Kumar, "Mind Your Education: Text of a Speech delivered at the National Seminar on Management Education at Banglaore on 26th July 2004," Paradigm, vol. 8, no. 1, hal. 15-19, Jan 2004.

10. K. Mather dan R. Seifert, "Teacher, lecturer or labourer? Performance management issues in education," Manag. Educ., vol. 25, no. 1, hal. 26-31, Jan 2011.

11. K. Li, M. Jing, X. Tao, dan Y. Duan, "Research on online management system of network ideological and political education of college students," Int. J. Electr. Eng. Educ., hal. 0020720920983704, Feb 2021.

12. D. K. Yadav, "Student Engagement at Higher Education Institutions: A Study of International Student Engagement and Motivational Challenges at Chinese Universities," Int. J. Educ. Reform, vol. 30, no. 3, hal. 237-254, Jun 2021.

13. S. Gorard, "Current Contexts for Research in Educational Leadership and Management," Educ. Manag. Adm. Leadersh., vol. 33, no. 2, hal. 155-164, Apr 2005.

14. S. Zhao, Z. Su, dan G. Miao, "Application of English education information management system based on convolution neural network classification algorithm,” Int. J. Electr. Eng. Educ., hal. 0020720920940614, Jul 2020.

15. Z. Pang, "Application of preschool education major in applied universities based on multimedia technology research on process management innovation in teaching process," Int. J. Electr. Eng. Educ., hal. 0020720920985041, Jan 2021.

16. C. H. Roch dan N. Sai, “Charter School Teacher Job Satisfaction,” Educ. Policy, vol. 31, no. 7, hal. 951-991, Jan 2016.

17. R. Doncaster, "Learning and Managing," Manag. Educ. Dev., vol. 10, no. 1, hal. 76-83, Mar 1979. 


\section{International Journal of Current Science Research and Review}

ISSN: 2581-8341

Volume 04 Issue 07 July 2021

DOI: 10.47191/ijesrr/V4-i7-24, Impact Factor: 5.825

IJCSRR@ 2021

www.ijcsrr.org

18. O. Chernikova, N. Heitzmann, M. Stadler, D. Holzberger, T. Seidel, dan F. Fischer, "Simulation-Based Learning in Higher Education: A Meta-Analysis," Rev. Educ. Res., vol. 90, no. 4, hal. 499-541, Jun 2020.

19. N. O. Pansiri, "Performativity in School Management and Leadership in Botswana," Educ. Manag. Adm. Leadersh., vol. 39, no. 6, hal. 751-766, Nov 2011.

20. C. Grant, "Emerging Voices on Teacher Leadership: Some South African Views," Educ. Manag. Adm.

21. Leadersh., vol. 34, no. 4, hal. 511-532, Okt 2006.

22. M. Jacobi, "Mentoring and Undergraduate Academic Success: A Literature Review," Rev. Educ. Res., vol. 61, no. 4, hal. 505-532, Des 1991.

23. S. Vergari, "The Politics of Charter Schools,” Educ. Policy, vol. 21, no. 1, hal. 15-39, Jan 2007.

24. M. Dobbins, "Convergent or divergent Europeanization? An analysis of higher education governance reforms in France and Italy," Int. Rev. Adm. Sci., vol. 83, no. 1, hal. 177-199, Sep 2015.

25. W. Sanjaya, Perencanaan dan Desain Sistem Pembelajaran. Jakarta: Kencana Perenada Media, 2010.

26. K. Narwana, "A global approach to school education and local reality: A case study of community participation in Haryana, India," Policy Futur. Educ., vol. 13, no. 2, hal. 219-233, Feb 2015.

27. D. S. Bahri dan A. Zain, Strategi Belajar Mengajar (Edisi Revisi). Jakarta: PT. Rineka Cipta, 2011.

28. M. J. Kimball, "Heritage Place Building Theory, Heritage Impact Assessment and the Role of the Sacred Dimension," J. Herit. Manag., vol. 2, no. 1, hal. 1-18, Jun 2017.

Cite this Article: Diodantara, Hasan Hariri, Sowiyah (2021). The Implementation of Learning Management in the Covid-19 Period in Junior High Schools in Indonesia: A Literature Review. International Journal of Current Science Research and Review, 4(7), 808-820 